\author{
Review Article
}

\title{
A CRITICAL REVIEW ON AVIPATHI CHOORNA- A UNIQUE FORMULATION FOR PEPTIC ULCER DISEASE
}

\section{Subha K Nampoothiri' ${ }^{*}$, A Shahul Hameed ${ }^{2}$}

*1PG Scholar, 2 Professor \& HOD, Department of Dravyagunavijnanam, Govt. Ayurveda College, Thiruvananthapuram, Kerala, India.

\begin{tabular}{|c|c|}
\hline io & \multirow{11}{*}{$\begin{array}{l}\text { ABSTRACT } \\
\text { Peptic-ulcer-disease is the ulceration of gasrtric or duodenal mucosa due to the digestive } \\
\text { action of pepsin and stomach acid. Gastritis, gastric ulcer and duodenal ulcer are included } \\
\text { under this. It can be correlated with the condition Parinamasoola mentioned in Ayurveda. } \\
\text { Avipathichoornam is a famous Ayurvedic formulation, mentioned in the texts Ashtanga } \\
\text { Hridaya and Sahasrayoga. Avipathi choorna exerts its effect in Peptic ulcer disease probably } \\
\text { through Deepana, Pachana and Saraka actions by virtue of the pharmacological properties } \\
\text { of the ingredients with which the vitiated Pitta can get normalized. It can be deducted that } \\
\text { Avipathi choorna probably neutralize the excess acid secretion in the gastrointestinal tract } \\
\text { and maintain a healthy pH. The formulation also probably acts by the anti inflammatory } \\
\text { property of most of the ingredients which can help pacify the inflamed tissue layer of the } \\
\text { gut. The aim of this paper is to demonstrate mode of action of Avipathi choorna in peptic } \\
\text { ulcer disease by critically analyzing the pharmacological properties as well as chemical } \\
\text { constituent of the ingredients. }\end{array}$} \\
\hline & \\
\hline & \\
\hline & \\
\hline & \\
\hline & \\
\hline & \\
\hline & \\
\hline & \\
\hline & \\
\hline & \\
\hline
\end{tabular}

\section{INTRODUCTION}

Peptic ulcer is one of the most prevalent chronic gastrointestinal disorders. It refers to an ulcer in the mucosa of lower oesophagus, stomach or the intestine. The ulceration results when the aggressive factors such as acid, pepsin, bile or Helicobacter pylori overwhelm the defensive factors of the gastrointestinal mucosa such as mucous and bicarbonate secretions, prostaglandins and nitric oxide. It affects $8-10 \%$ of the global population.[1]

Peptic-ulcer disease includes many conditions like gastritis, gastric ulcer and duodenal ulcer. The cardinal feature of peptic ulcer disease is sharp and burning epigastric pain, which may be ill defined and often aggravated by meals or relieved few minutes after a meal. Other associated symptoms include nausea, vomiting, flatulence, abdominal distention, water brash etc. ${ }^{[2]}$ It can be compared to the disease Parinamasoola mentioned in Ayurveda.

\begin{tabular}{|l|l|}
\hline \multicolumn{3}{|c|}{ Access this article online } \\
\hline Quick Response Code & \begin{tabular}{l} 
https://doi.org/10.47070/ijapr.v9i9.2038 \\
\hline
\end{tabular} \\
\cline { 2 - 3 }
\end{tabular}

Parinama shoola is characterised by burning sensation along with pain in epigastrium during the digestion of ingested food.

The disease Parinama shoola was first mentioned by Acharya Madhava in his treatise on etiopathology of diseases. Though it is a Pitta predominant disease, there is involvement of the other two Doshas in its etiopathogenesis. Pitta (Pachaka pitta) gets vitiated, Kapha (Kledaka kapha) gets vitiated, dislodged and gets combined with deranged Vata (Samana vayu), and precipitates Parinamasoola. [3]

There is a scope for introduction of a safe alternative to the present day anti ulcer drugs. Avipathi choorna, a poly herbal Ayurvedic formulation, is mentioned in the texts Sahasrayoga and Ashtanga

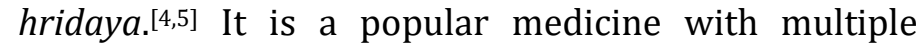
indications. This medicine has been used by the Ayurvedic practitioners for the management of peptic ulcer disease. Ingredients of Avipathi choorna are economical, safe and are easily available.

The principle of management of Parinama shoola is amelioration of the provoked Vata, alleviation of provoked Pitta and reinstation of Kapha. Virechana (Purgation) is the main treatment in Parinamasoola. ${ }^{[6]}$ Virechana is useful in disorders in which Pitta is associated with Kapha. Avipathi choorna is mainly 
indicated in diseases of Pitta predominance in lower doses as Samana (alleviating) and in higher doses as Virechana (purgation) medication.

\section{Avipathi choorna}

The name Avipathi literally means that which is not harmful. The drugs included in the formulation are Sunthi:- dried rhizome of Zingiber officinale, Marichafruit of Piper nigrum, Pippali- fruit of Piper longum, Twak- bark of Cinnamomum zeylanicum, Ela- seeds of Eletteria cardomomum, Patra- leaves of Cinnamomum tamalaum, Musta- tubers of Cyperus rotundus, Vidangaseeds of Embelia ribes, Amalaki- fruit rind of Embilica officinalis- 1 part each, Trivrit- root of Operculina turpethum- 9 parts and Sita (Candy sugar) -18 parts. Honey is given as vehicle.[5] The dose is $12 \mathrm{gm}$ in divided doses after food. The dose for purgation is $12 \mathrm{gm}-48 \mathrm{gm}$, given as a single dose after the digestion of last meal.[7] More over Charaka has included three of the above drugs, Pippali, Sunthi and Maricha in Soolahara (abdominal pain relievers) group. ${ }^{[8]}$

\section{METHODOLOGY}

A detailed critical review was carried out in all available literature as classical Ayurvedic books and online databases. Review mainly focused on pharmacological properties of each ingredient as per Ayurvedic perspective and that of their chemical constituents in modern perspective.

\section{RESULTS AND DISCUSSSION}

\section{Pharmacological Profile as per Ayurveda}

Pharmacological profile of a drug according to Ayurveda includes their properties as Rasa, Guna, Veerya, Vipaka and its effect (Karma). The Pharmacological profile of the ingredients of Avipathi choorna are analysed and depicted in the following table:

Table: 1 Pharmacological Actions as per Ayurveda

\begin{tabular}{|c|c|c|c|c|c|}
\hline Sanskrit Name & Rasa & Guna & Veerya & Vipaka & Karma \\
\hline Sunthi & Katu & $\begin{array}{l}\text { Laghu } \\
\text { Snigdha }\end{array}$ & Ushna & Madhura & $\begin{array}{l}\text { Vatakaphahara } \\
\text { Deepana Pachana, } \\
\text { Soolahara[9] }\end{array}$ \\
\hline Maricham & Katu & $\begin{array}{l}\text { Laghu } \\
\text { Rooksha } \\
\text { Teekshna }\end{array}$ & Ushna & Katu & $\begin{array}{l}\text { Vatakaphahara Deepana } \\
\text { Soolahara }{ }^{10]}\end{array}$ \\
\hline Pippali & Katu & $\begin{array}{l}\text { Laghu } \\
\text { Snigdha }\end{array}$ & Anushna & Madhura & $\begin{array}{l}\text { Vatakaphahara Deepana } \\
\text { Soolahara }{ }^{111]}\end{array}$ \\
\hline Twak & $\begin{array}{l}\text { Katu } \\
\text { Tikta } \\
\text { Madhura }\end{array}$ & $\begin{array}{l}\text { Laghu } \\
\text { Teekshna }\end{array}$ & Ushna & Katu & $\begin{array}{l}\text { Vatakaphahara } \\
\text { Deepana Pachana [12] }\end{array}$ \\
\hline Patra & $\begin{array}{l}\text { Katu } \\
\text { Madhura }\end{array}$ & $\begin{array}{l}\text { Laghu } \\
\text { Snigdha } \\
\text { Pichila }\end{array}$ & Ushna & Katu & Kaphavatahara [13] \\
\hline Ela & $\begin{array}{l}\text { Katu } \\
\text { Madhura }\end{array}$ & Laghu & Sita & Madhura & Kaphavatahara [14] \\
\hline Musta & $\begin{array}{l}\text { Tikta } \\
\text { Katu } \\
\text { Kashaya }\end{array}$ & $\begin{array}{l}\text { Laghu } \\
\text { Rooksha }\end{array}$ & Sita & Katu & $\begin{array}{l}\text { Kaphapittahara } \\
\text { Deepana Pachana [15] }\end{array}$ \\
\hline Vidanga & $\begin{array}{l}\text { Katu } \\
\text { Kashaya }\end{array}$ & $\begin{array}{l}\text { Laghu } \\
\text { Rooksha } \\
\text { Teekshna }\end{array}$ & Ushna & Katu & $\begin{array}{l}\text { Kaphahara } \\
\text { Krimighna } \\
\text { Deepana } \\
\text { Soolahara }{ }^{[16]}\end{array}$ \\
\hline Amalaki & $\begin{array}{l}\text { Amla, katu } \\
\text { Kashaya } \\
\text { Tikta } \\
\text { Madhura }\end{array}$ & $\begin{array}{l}\text { Laghu } \\
\text { Rooksha }\end{array}$ & Sita & Madhura & $\begin{array}{l}\text { Tridoshahara } \\
\text { Deepana }{ }^{[17]}\end{array}$ \\
\hline Trivrit & $\begin{array}{l}\text { Madhura } \\
\text { Katu }\end{array}$ & $\begin{array}{l}\text { Laghu } \\
\text { Rooksha }\end{array}$ & Ushna & Katu & $\begin{array}{l}\text { Kaphapittahara } \\
\text { Rechana }\end{array}$ \\
\hline
\end{tabular}


Int. J. Ayur. Pharma Research, 2021;9(9):80-85

\begin{tabular}{|l|l|l|l|l|l|}
\hline & $\begin{array}{l}\text { Tikta } \\
\text { Kashaya }\end{array}$ & Teekshna & & Vranahara [18] \\
\hline Sita & Madhura & $\begin{array}{l}\text { Guru } \\
\text { Snigdha } \\
\text { Sita }\end{array}$ & Sita & Madhura & Rakthapittahara [19] \\
\hline Madhu & $\begin{array}{l}\text { Madhura } \\
\text { Kashaya } \\
\text { anurasa }\end{array}$ & $\begin{array}{l}\text { Laghu } \\
\text { Rooksha }\end{array}$ & Sita & Madhura & $\begin{array}{l}\text { Kaphapittahara } \\
\text { Deepana } \\
\text { Vranaropana } \\
\text { Sandhana [20] }\end{array}$ \\
\hline
\end{tabular}

\section{Pharmacological Actions- Modern view}

In modern view, phytoconstituents are responsible for the pharmacological effects of a herbal drug. The important phytoconstituents of each ingredients of Avipathi Choorna and their pharmacological actions are analyzed and shown in the table below:

Table 2: Pharmacological Actions- Modern View

\begin{tabular}{|c|c|c|c|}
\hline $\begin{array}{l}\text { Sanskrit } \\
\text { Name }\end{array}$ & $\begin{array}{l}\text { English/Scientific } \\
\text { name and Family }\end{array}$ & Chemical constituents & $\begin{array}{l}\text { Reported } \\
\text { Pharmacological actions }\end{array}$ \\
\hline Sunthi & $\begin{array}{l}\text { Zingiber Officinale } \\
\text { Roscoe. } \\
\text { Zingiberaceae }\end{array}$ & $\begin{array}{l}\text { Zingerone } \\
\text { Gingerol Flavonoids }\end{array}$ & $\begin{array}{l}\text { Anti-oxidant } \\
\text { Anti-inflammatory }{ }^{[21]} \\
\text { Gastroprotective }{ }^{22]}\end{array}$ \\
\hline Maricham & $\begin{array}{l}\text { Piper nigrum Linn. } \\
\text { Piperaceae }\end{array}$ & $\begin{array}{l}\text { Piperine } \\
\text { Piperidine } \\
\text { Flavonoids }\end{array}$ & $\begin{array}{l}\text { Appetiser } \\
\text { Anti -inflammatory } \\
\text { Antacid, stimulant } \\
\text { Digestive }{ }^{[21]}\end{array}$ \\
\hline Pippali & $\begin{array}{l}\text { Piper longum Linn. } \\
\text { Piperaceae }\end{array}$ & $\begin{array}{l}\text { Piperine } \\
\text { Zingiberene } \\
\text { Flavonoids }\end{array}$ & $\begin{array}{l}\text { Anti-inflammatory } \\
\text { Anti-oxidant } \\
\text { Anti-microbial } \\
\text { Analgesic [23] }\end{array}$ \\
\hline Twak & $\begin{array}{l}\text { Cinnamomum } \\
\text { Zeylanicum Blume. } \\
\text { Lauraceae }\end{array}$ & $\begin{array}{l}\text { Tannin } \\
\text { CinnamaldehydeFlavonoids }\end{array}$ & $\begin{array}{l}\text { Anti-inflammatory }{ }^{[24]} \\
\text { Gastroprotective }{ }^{[25]}\end{array}$ \\
\hline Patra & $\begin{array}{l}\text { Cinnamomum tamala } \\
\text { Demot. Lauraceae }\end{array}$ & $\begin{array}{l}\text { Cinnamaldehyde } \\
\text { Flavonoids }\end{array}$ & $\begin{array}{l}\text { Anti-oxidant [26] } \\
\text { Gastroprotective [27] }\end{array}$ \\
\hline Ela & $\begin{array}{l}\text { Eletteria cardamomum } \\
\text { Maton } \\
\text { Scitaminae }\end{array}$ & Volatile oil & $\begin{array}{l}\text { Anti-inflammatory } \\
\text { Analgesic } \\
\text { Antioxidant } \\
\text { Gastroprotective [28] }\end{array}$ \\
\hline Musta & $\begin{array}{l}\text { Cyperus rotundus Linn. } \\
\text { Cyperaceae }\end{array}$ & $\begin{array}{l}\text { Flavonoids } \\
\text { Cineol, tannins }\end{array}$ & $\begin{array}{l}\text { Antibacterial } \\
\text { Anti-inflammatory } \\
\text { Analgesic } \\
\text { Gastroprotective [29] }\end{array}$ \\
\hline Vidanga & $\begin{array}{l}\text { Embelia ribes Burn. F. } \\
\text { Primulaceae }\end{array}$ & $\begin{array}{l}\text { Tannin } \\
\text { Volatile oil }\end{array}$ & $\begin{array}{l}\text { Analgesic } \\
\text { Anti-inflammatory [30] } \\
\text { Antioxidant } \\
\text { Anthelminthic } \\
\text { Wound healing [31] }\end{array}$ \\
\hline Amalaki & $\begin{array}{l}\text { Emblica officinalis } \\
\text { Gareth. } \\
\text { Euphorbaceae }\end{array}$ & $\begin{array}{l}\text { Tannin, saponin } \\
\text { Phenolic compounds }\end{array}$ & $\begin{array}{l}\text { Antioxidant } \\
\text { Analgesic } \\
\text { Anti inflammatory }\end{array}$ \\
\hline
\end{tabular}




\begin{tabular}{|c|c|c|c|}
\hline & & Gallicacid & $\begin{array}{l}\text { Antiulcer } \\
\text { Gastro-protective [32] }\end{array}$ \\
\hline Trivrit & $\begin{array}{l}\text { Operculina turpethum } \\
\text { Linn. } \\
\text { Convolvulaceae }\end{array}$ & $\begin{array}{l}\text { Scopoletin } \\
\text { Tannins } \\
\text { Saponins } \\
\text { Turpethin }\end{array}$ & $\begin{array}{l}\text { Antibacterial } \\
\text { Anti-inflammatory } \\
\text { Analgesic[33] } \\
\text { Ulcer protective [34] }\end{array}$ \\
\hline Sita & Candy sugar & Flavonoids & $\begin{array}{l}\text { Anti-oxidant } \\
\text { Energy booster [35] }\end{array}$ \\
\hline Madhu & Honey & $\begin{array}{l}\text { Phenol, Saponins } \\
\text { Flavonoids } \\
\text { Tannin }\end{array}$ & $\begin{array}{l}\text { Anti-oxidant } \\
\text { Antimicrobial } \\
\text { Anti-bacterial } \\
\text { Wound healing [36] }\end{array}$ \\
\hline
\end{tabular}

Most of the drugs in Avipathi choorna possess anti-inflammatory, anti-oxidant and gastroprotective properties. Experimental studies also reveal the antiulcer and gastoprotective effects of some ingredients and that of the formulation Avipathichoorna. ${ }^{[37]}$

\section{DISCUSSION}

\section{Peptic ulcer}

In the modern aspect, etiolgy of Peptic ulcer include over production of gastric acid and decreased secretions of protective gastric mucosa which leads to symptoms of peptic ulcer disease and consequently the erosion of mucosa. So the main aim of the treatment is to heal the ulcer, relieve pain, prevent complications and relapse.

\section{Parinamasola}

The Peptic ulcer disease is comparable with pathological condition named Parinamasoola in Ayurveda. The etiopathogenesis of Parinamasoola, involves all the three Doshas (Vata, Pitta and Kapha). So the line of treatment is the amelioration of the provoked Vata, alleviation of provoked Pitta and reinstation of Kapha. The disease occurs in the Mahasrothas (digestive tract) and there is derangement of Agni. Therefore the drug chosen should be having Deepana (improves appetite), and Pachana (improves digestion) property, which is essential for eliminating the root cause of the disease.

\section{Mode of action of Avipathichoorna}

\section{Ayurvedic view}

Avipathichoorna, is a classical formulation which can be of promising effect in the management of Parinamasoola. Among the ingredients, Twak, Patra, Ela, Vidanga, Maricha and Sita have capability to ameliorate Vata. Trivrit, Musta, Sita and Amalaki have capability to alleviate Pitta. Musta, Twak, Patra, Ela, Sunthi, Maricha, Pippali, Trivrit and Madhu are capable of normalising Kapha and reinstating it. Sunthi, Maricha, Pippali, Musta, Amalaki, Madhu, Twak, Patra, Ela and Vidanga can improve Agni (digestants). Madhu is also having Vranaropana (wound healing) property, which probably aids in healing ulcer. Amalaki is Rasayana and can strengthen the tissues. The dosage form Choorna (powder) can also have a physical effect of adsorption there by reducing excessive Dravatha of Pitta. Moreover inclusion of Pippali, Sunthi and Maricha in the Soolaprasamana group by Charaka further supports the claimed effect of the formulation in this disease. Thus it can be assumed that Avipathi choorna mainly acts by its Deepana, Pachana and Saraka guna which normalizes the vitiated Pitta.

\section{Modern Pharmacological Action}

Trivrit, one of the main ingredients of the formulation, increases the mucous secretion. Scopoletin present in Trivrit helps to reduce acidity. Tannins are reported in Trivrit, Twak, Vidanga, Musta, Amalaki and honey. Tannin is effective against Helicobacter pylori. Tannins also exhibit antioxidant action and also aids in gastrointestinal tract antiinflammatory processes. Flavonoids, reported to be present in Sunthi, Pippali, Maricha, Twak, Patra, Musta, Sita and honey, are highly gastroprotective by increasing the mucosal prostaglandin levels and inhibiting the release of histamine.

Piperine present in Maricha and Pippali also exert cytoprotective effects on the gastric mucosa. Sunthi decreases the gastric secretion, increases the mucosal resistance and potentiates the defensive factors of gastric mucosa. It also increases blood circulation around the stomach and thus aids in healing. Twak and Patra contain E-cinnamaldehyde and o-methoxy cinnamaldehyde, both of which show anti-inflammatory property. Phenolic compounds in Amalaki fruit can reduce acute and chronic inflammatory response via antioxidant action. Also Saponins in Trivrit, Amalaki and Madhu is having gastroprotective effect by increasing the mucous production. Thus the ingredients of Avipatti choorna exhibit antiulcer properties. It can be inferred that the carminative, anti-oxidant and antiinflammatory property of Avipathi choorna aids in normalizing gastric secretions. 
Research evidence also reveals the anti-ulcer effects of the ingredients such as Trivrit, Sunthi, Pippali, Twak, Patra and also the gastroprotective activity of Avipathichoorna. Considering all these aspects it can be assumed that Avipathichoorna is a good and safe therapeutic agent for treating Peptic ulcer disease.

\section{CONCLUSION}

On analysing the pharmacological properties of each ingredient in the formulation, it can be concluded that Avipathi Choorna has promising effect in the management of peptic ulcer disease.

\section{REFERENCES}

1. Sung, J. J., Kuipers, E. J., \& El-Serag, H. B. Systematic review: The global incidence and prevalence of Peptic ulcer disease. Alimentary pharmacology \& therapeutics. 2009; 29(9): 938946.

2. Fauci AS, Braunwald E, Kasper DL, Hauser SL, Longo DL, Jameson JL. Harrison's Principles of Internal Medicine. 17 ed. New York; McGraw Hill; 2005. p.1751.

3. Sri Sudarshan Shastri, Yadunandana Upadhyay. Madhava Nidanam (Madhukosha Sanskrit Commentary). Varanasi; Chaukhambha Prakashan; 2009. p.512.

4. Krishnan Vaidyan K.V, Gopalapillai S. Sahasrayoga, 33rd ed. Alappuzha; Vidyarambham Publishers; 2015. p.163.

5. Dr Kanjiv Lochan. Ashtanga Hridaya of Vagbhata. Varanasi; Chaukhamba Sanskriti Sansthan; 2017. p.495.

6. Laxmipati Shastri, Brahmshankar Shastri. Yoga Ratnakar (Hindi Commentary). Varanasi; Chaukhamba Prakashan; 2009. p.13.

7. Sreekanthamurthy K.R. Sarngadhara samhitha, (English translation). Reprint 2012. Varanasi; Chaukhamba Orientalia; 2009. p.205.

8. Sharma R.K and Bhagwan Dash. Charaka Samhita Sutrasthana text with English translation. Reprint ed. Varanasi; Chowkhambha Sanskrit Series Office; 2018. p.910.

9. Sreekandha murthy K.R. Bhavaprakasha (English commentary). Varanasi; Chaukhambha Krishnadas academy; 2008. p.165

10. Sreekandha murthy K.R. Bhavaprakasha (English commentary). Vol.1.Varanasi: Chaukhambha Krishnadas academy; 2008. p.167.

11. Sreekandhamurthy K.R. Bhavaprakasha (English commentary). Vol.1. Varanasi; Chaukhambha Krishnadas academy; 2008. p.166.

12. Sreekandhamurthy K.R. Bhavaprakasha (English commentary). Vol.1. Varanasi; Chaukhambha Krishnadas academy; 2008. p.216.

13. Sreekandha murthy K.R. Bhavaprakasha (English commentary). Vol.1 Varanasi; Chaukhambha Krishnadas academy; 2008. P.217.
14. Sreekandha murthy K.R. Bhavaprakasha (English commentary). Vol.1.Varanasi; Chaukhambha Krishnadas academy; 2008. p.216.

15. Sreekandha murthy K.R. Bhavaprakasha (English commentary) Vol.1. Varanasi; Chaukhambha Krishnadas academy; 2008. p.220.

16. Dr. Gyanendra Pandey. Dravyaguna vijnana. Vol.II. Varanasi; Chaukhambha Krishnadas Academy; 2007. p:642.

17. Sreekandha murthy K.R. Bhavaprakasha (English commentary). Vol.1. Varanasi; Chaukhambha Krishnadas academy; 2008. p.164.

18. Sreekandha murthy K.R. Bhavaprakasha (English commentary). Vol.1. Varanasi; Chaukhambha Krishnadas academy; 2008. p.214.

19. Sreekandha murthy K.R. Bhavaprakasha (English commentary). Vol.1. Varanasi; Chaukhambha Krishnadas academy; 2008. p.494-495

20. Sreekandha murthy K.R. Bhavaprakasha (English commentary). Vol.1. Varanasi; Chaukhambha Krishnadas academy; 2008. p.485- p.489.

21. Chithra.M.S Pooja.P, K. Unnikrishna Pillai, Ramesh N.V, Abhaya Kumar Mishra. Multi-dimensional action of Trikatu. AAMJ. 2016; 2(1): 17-18.

22. Al-Yahya MA, Rafatullah S, Mossa JS, Ageel AM, Parmar NS, Tariq M. Gastroprotective activity of ginger- zingiber officinale rosc., in albino rats. Am J Chin Med. 1989; 17(1-2): 51-56.

23. Agrawal AK, Rao CV, Sairam K, Joshi VK, Goel RK. Effect of Piper longum Linn, Zingiber officianalis Linn and Ferula species on gastric ulceration and secretion in rats. Indian J Exp Biol. 2000; 38(10): 994-8.

24. Ranasinghe, Priyanga, Shehani, Sirimal, Galapathy. Medicinal properties of true cinnamon (Cinnamomum zeylanicum): A systematic review. BMC complementary and alternative medicine. 2013; 10(3): 32-34.

25. Mohammed Asad, Antiulcer Effect of Cinnamomum zeylanicum Bark in Rats. Research Journal of Biological Sciences. 2014; 3(9): 182187.

26. Mehta, Seema \& Purohit, Vijay \& Andola, Harish. Pharmacological Activities of Cinnamomum tamala Nees \& Eberm. and Medical Implication: A Review. Medicinal \& Aromatic Plants. 2014; 2(4): 12-13.

27. Eswaran MB, Surendran S, Vijayakumar M, Ojha SK, Rawat AK. Gastroprotective activity of Cinnamomum tamala leaves on experimental gastric ulcers in rats. J Ethnopharmacol. 2010; 128(2): 537-40.

28. Korikanthimathm, V.S \& Prasath, D. \& Rao. Govardhana. Medicinal properties of Elettaria cardamomum. J Med Aromat Plant Sci. 2001; 1(2): 22-23. 
29. Meena A.K, Yadav A K, Niranjan U S, Singh B, Nagariya A K. Review on Cyperus rotundusA potential Herb. Int J Pharmcaeut Clin Res. 2010; 2(1): 20-22.

30. Bist, Meenu \& Prasad, Dr. Shyam. Embelia ribes: A valuable medicinal plant. Journal of Chemical and Pharmaceutical Research. 2016; 4(2): 1229-1233.

31. Srinath Ambati, Jyothi.V and Asha Jyothi.V. Pharmacological, pharmacognostic and phytochemical review of Embelia ribes. IJPT. 2010; 3(2): 525- 539.

32. Al-Rehaily, A. J., Al-Howiriny, T. A., Al-Sohaibani, M. O., \& Rafatullah, S. (2002). Gastroprotective effects of 'Amla' Emblica officinalis on in vivo test models in rats. Phytomedicine: International journal of phytotherapy and phytopharmacology. 9(6): 515-522.

33. Kolhe, Rasika \& Acharya, Rabinarayan. Trivrit and Its Important in the Classical Text of Ayurveda: A Comprehensive Review. Research and Reviews:
Journal of Ayurvedic Science, Yoga and Naturopathy. 2014; 4(3): 33-53.

34. Vidya Ignatius, Madhusudan Narayan, Venkataraman, Antiulcer activity of Indigenous plant Operculina turpethum Linn. Evidence based Complementary and Alternative medicine. 2013; 5(3):14-16

35. Singh A, Lal UR, Mukhtar HM, Singh PS, Shah G, Dhawan RK. Phytochemical profile of sugarcane and its potential health aspects. Pharmacognosy Rev. 2015; 9(17): 45-54.

36. Saranraj, P. \& Sivasakthi, S \& Feliciano, Glaucio. Pharmacology of Honey: A Review. Biological research. 2016; 2(4): 271-289.

37. D. Benito Johnson, C. Senthil Kumar, C. Glince Raphael, R. Venkatnarayanan and Siraj Kattupparuthi. Gastroprotective Activity of Avipathi Choornam. Research Journal of Pharmacognosy and Phytochemistry. 2013; 5(1): 37-41.

\section{Cite this article as:}

Subha K Nampoothiri, A Shahul Hameed. A Critical Review on Avipathi Choorna- A Unique Formulation For Peptic Ulcer Disease. International Journal of Ayurveda and Pharma Research. 2021;9(9):80-85.

https://doi.org/10.47070/ijapr.v9i9.2038

Source of support: Nil, Conflict of interest: None Declared
*Address for correspondence Dr. Subha K Nampoothiri

PG Scholar,

Dept of Dravyagunavijnanam,

Govt. Ayurveda College,

Thiruvananthapuram,

Kerala, India.

Email:

subhanamboothiri@gmail.com

Mobile: 9446511932

Disclaimer: IJAPR is solely owned by Mahadev Publications - dedicated to publish quality research, while every effort has been taken to verify the accuracy of the content published in our Journal. IJAPR cannot accept any responsibility or liability for the articles content which are published. The views expressed in articles by our contributing authors are not necessarily those of IJAPR editor or editorial board members. 